\title{
Nitrogen and phosphorus fertilization of improved varieties for enhancing yield and yield components of wheat
}

\author{
Shazma Anwar, Israeel, Babar Iqbal*, Shehryar Khan, Muhammad \\ Faraz, Nawab Ali, Saddam Hussain and Muhammad Mehran Anjum \\ Department of Agronomy, University of Agriculture, Peshawar - Pakistan \\ *Corresponding author's email: agronomist19388@yahoo.com \\ Citation \\ Shazma Anwar, Israeel, Babar Iqbal, Shehryar Khan, Muhammad Faraz, Nawab Ali, Saddam Hussain and \\ Muhammad Mehran Anjum. Nitrogen and phosphorus fertilization of improved varieties for enhancing yield \\ and yield components of wheat. Pure and Applied Biology. Vol. 5, Issue 4, pp727-737.
}

http://dx.doi.org/10.19045/bspab.2016.50091

\begin{tabular}{llll}
\hline \hline Received: 04/01/2016 & Revised: 25/072016 & Accepted: 02/08/2016 & Online First: 08/08/2016 \\
\hline \hline
\end{tabular}

\section{Abstract}

A field experiment was conducted at New Developmental Farm, The University of Agriculture Peshawar during rabi 2012-2013 to study the effect of $\mathrm{N}$ and P fertilization of improved varieties for enhancing yield and yield components of wheat varieties. Randomized Complete Block (RCB) Design with split plot arrangement having three replications was used. A sub plot size of $12 \mathrm{~m}^{2}$ having ten rows of $4 \mathrm{~m}$ length was used. $\mathrm{N}$ levels $(100,125$ and $150 \mathrm{~kg}$ $\left.\mathrm{ha}^{-1}\right)$ and $\mathrm{P}$ levels $\left(60,90\right.$ and $\left.120 \mathrm{~kg} \mathrm{ha}^{-1}\right)$ were applied to the main plots and wheat varieties (Siran-2010 and Atta-Habib) were assigned to the sub plots and one control having no $\mathrm{N}$ and $\mathrm{P}$ was maintained in main plot treatment. All of the phosphorus and half of the nitrogen were applied at sowing time. The remaining $\mathrm{N}$ was applied at tillering stage. The results of the experiment showed that maximum tillers $\mathrm{m}^{-2}(377)$, spikes $\mathrm{m}^{-2}(362)$, grains spikes ${ }^{-1}(50.67)$, thousands grains weight $(41.16 \mathrm{~g})$, biological yield $\left(10060 \mathrm{~kg} \mathrm{ha}^{-1}\right)$, grain yield (3855 $\left.\mathrm{kg} \mathrm{ha}^{-1}\right)$ and harvest index $(38.7 \%)$ were produced by Siran-2010 while maximum nonproductive tillers $\mathrm{m}^{-2}(18)$ was maintained by Atta-Habib. The plots that received nitrogen at the rate of $62.5 \mathrm{~kg} \mathrm{ha}^{-1}$ produced maximum tillers $\mathrm{m}^{-2}$ (383). Maximum spikes $\mathrm{m}^{-2}(368)$, grains spikes ${ }^{-1}$ (51.44), thousand grains weight $(42.16 \mathrm{~g})$, grain yield $\left(4061 \mathrm{~kg} \mathrm{ha}^{-1}\right)$ and harvest index (40.9 $\%$ ) were produced by $125 \mathrm{~kg} \mathrm{~N}^{-1}$ while nitrogen application at the rate of $150 \mathrm{~kg} \mathrm{ha}^{-1}$ produced maximum biological yield $\left(10386 \mathrm{~kg} \mathrm{ha}^{-1}\right)$. Phosphorus application at the rate of 90 $\mathrm{kg} \mathrm{ha}^{-1}$ produced highest number of tillers $\mathrm{m}^{-2}(379)$, spikes $\mathrm{m}^{-2}(364)$, grains spikes ${ }^{-1}(52.44)$, thousand grains weight $(41.21 \mathrm{~g})$, biological yield $\left(10298 \mathrm{~kg} \mathrm{ha}^{-1}\right)$, grain yield (3944 kg ha-1) and harvest index $(38.8 \%)$. It is concluded that wheat variety Siran-2010 produced higher grain yield when treated with $125 \mathrm{~kg} \mathrm{~N} \mathrm{ha}^{-1}$ and $90 \mathrm{~kg} \mathrm{P} \mathrm{ha}^{-1}$.

Keywords: Wheat (Triticum aestivum L.); Varieties; Nitrogen; Phosphorus; Yield and yield components

\section{Introduction}

Wheat (Triticum aestivum L.) is the major crop among the cereal in the world and it has been playing a vital role in cultural and economic development since immemorial time. Wheat is known as the king of cereal. It has greater significance in Pakistan in preventing food demand of the people [1, 2]. Wheat is the basic staple food of Pakistan. Wheat grain contains 12 $\%$ protein and provides about $73 \%$ calories [3]. Wheat grains can be directly 
or indirectly used as human food and its straw is used as animal feed. In Pakistan the total area under cultivation of wheat crop was 8.9 million ha, that produce 25.21 million tons of food grain with mean production of $2833 \mathrm{~kg} \mathrm{ha}^{-1}$, while in KPK wheat is cultivated over an area of about 0.72 million ha, which produce 1.11 million tones with average production of $1595 \mathrm{~kg} \mathrm{ha}^{-1}$ [4]. The leading producer of wheat in Pakistan is Punjab. In KPK, more wheat is grown in barani $(61 \%)$ than irrigated area (39\%). As compared to others developing countries wheat production in Pakistan is very low. Quality production and improvement in yield can be achieved by use of balanced nutrient application especially NPK to improved varieties of wheat crop [5]. Besides grain, wheat straw (bhossa) can also be used as roughage for livestock. In order to get highest grain yield selection of the best suited variety is very important. Cultivars are selected on the basis of various characteristics such as straw strength, grain quality and climatic adaptability etc. Fertilizer application at proper time in balance proportion with proper method of application gave better impact on crop productivity [6]. $\mathrm{N}$ is essential for growth, protein synthesis, vigorous vegetative growth, chlorophyll and deep green color. Nitrogenous fertilizers are used by the farmers in much larger amount than any other fertilizer. This is because plants needed nitrogen in much larger amount than any other nutrient. Moreover our soil is deficient in this most demanding nutrient. On world basis nitrogen application is about 80 million tons [7]. To meet the increasing demand of food for increasing population of the world developing countries apply more and more fertilizers. In 2012 the world population will be more than eight million [8]. However, the fertilizer $\mathrm{N}$ efficiency tends to be low in this system [9].

The chemical fertilizers are the most important source of the readily available nitrogen for the crop growth. Due to the greater availability [10] and crucial input for enhancing crop productivity [11], $\mathrm{N}$ is a vital part of modern technology for enhancing crop productivity. Nitrogen is one of the major limiting elements for crop growth and development [12]. However effective $\mathrm{N}$ management presents greater challenge to the farmers than other fertilizer nutrients [13]. The availability of $\mathrm{N}$ can be enhanced by its proper time of application, and better strategies to increase crop production. Application of $\mathrm{N}$ improves various growth parameters like fertile tillers $\mathrm{m}^{-2}$ [14], grain yield [15], thousands grain weight [16], more productive tillers [17]. Different nitrogen and phosphorus levels significantly effect the agronomic parameters like, plant height, grain spike, thousand grain weight and root biomass [18].

Phosphorus is essential for many physiological processes, such as storage of energy and its transfer, respiration, photosynthesis, cell division and cell enlargement etc. Phosphorous is involved in the synthesis of energy rich phosphate compound such as adenosine triphosphat (ATP) and adenosine diphosphat (ADP) which derive various biochemical reactions within the plant. Phosphorus role in plant is not limited to metabolic reactions. Phosphorus is a structural component of nucleic acid (DNA, RNA) nucleotide, phospholipids and phosphoprotiens. The movement of applied phosphatic fertilizer in soil is just only $3-4 \mathrm{~cm}$. Consequently, it is hardly available to the extent of $15-20 \%$ to the plant. The rest goes to waste from immediate crop being fixed in soil [19]. Phosphorus application at proper time, in optimum quantity through proper method of application is essential to increase crop production and its sustainability [20].

Phosphorous deficiency in the soil reduced crop response to nitrogen [21]. Crop required proper amount of phosphorus for the initiation of leaves and florets primomordial [22]. Whenever a plant breeder develops a new variety it is very 
important to find out the production technology of that variety especially with reference to the requirement of $\mathrm{N}$ and $\mathrm{P}$ as the nutritional requirement of different variety of the same species may vary due to agro-climatic conditions of the region and their yield potential [23]. Phosphorous is an important element that impacts on zinc uptake, as by increasing phosphorous level in soil zinc uptake by plant is reduced [24]. The rate and form of $\mathrm{N}$ and $P$ fertilizers can effect plant growth response to mycorrhizal inoculation. The basic role of commercial fertilizer is to enhance crop productivity but the greatest problem is the minimum use of phosphatic fertilizer in obtaining maximum crop production than nitrogenous fertilizer [25]. With reference to the important role of $\mathrm{N}$ and $\mathrm{P}$ in crop productivity, this research study was planned to evaluate the effect of various phosphorous and nitrogen levels on wheat varieties.

\section{Materials and methods}

An experiment on nitrogen and phosphorus fertilization of improved varieties for enhancing yield and yield components of wheat was carried out at New Developmental Farm, The University of Agriculture, Peshawar during winter season 2012-2013. The experiment was arranged in a randomized complete block design with three replications in split plot arrangement. Size of the sub plots was $4 \mathrm{x}$ $3 \mathrm{~m}^{2}$. Seed rate of $120 \mathrm{~kg} \mathrm{ha}^{-1}$ was used. Urea and SSP fertilizers were used as $\mathrm{N}$ and $\mathrm{P}$ sources respectively. All of the $\mathrm{P}$ and half of the $\mathrm{N}$ fertilizers were applied at sowing. The rest of the $\mathrm{N}$ was applied at tillering stage. One control having no $\mathrm{N}$ and $\mathrm{P}$ was maintained in main plot treatment. The experiment was consisted of treatments which are nitrogen levels and phosphorus levels which are assigned to Main plots and levels are $\mathrm{N}_{1}\left(100 \mathrm{~kg} \mathrm{ha}^{-1}\right)$, $\mathrm{N}_{2}\left(125 \mathrm{~kg} \mathrm{ha}^{-1}\right), \mathrm{N}_{3}\left(150 \mathrm{~kg} \mathrm{ha}^{-1}\right)$ where $\mathrm{P}$ levels are $\mathrm{P}_{1}\left(60 \mathrm{~kg} \mathrm{ha}^{-1}\right), \mathrm{P}_{2}\left(90 \mathrm{~kg} \mathrm{ha}^{-1}\right)$, $\mathrm{P}_{3}\left(120 \mathrm{~kg} \mathrm{ha}^{-1}\right)$. Subplot included wheat varieties which are $\mathrm{V}_{1}$ (Siran-2010) and $\mathrm{V}_{2}$ (Atta-Habib). Data was recorded on parameters which are number of tillers $\mathrm{m}^{-2}$, spike $\mathrm{m}^{-2}$, grain spike $^{-1}$, thousand grains weight $(\mathrm{g})$, biological yield $\left(\mathrm{kg} \mathrm{ha}^{-1}\right)$, grain yield $\left(\mathrm{kg} \mathrm{ha}^{-1}\right)$ and harvest index $(\%)$. In each sub plot three rows of one meter length were selected randomly to count tillers $\mathrm{m}^{-2}$ and change accordingly to tillers $\mathrm{m}^{-2}$. Spikes $\mathrm{m}^{-2}$ was recorded by counting spikes in three randomly selected central rows in each sub plots and changed to productive tillers $\mathrm{m}^{-2}$ accordingly. In each sub plot ten spikes were selected randomly and grains were counted and averaged to calculate grains spike ${ }^{-1}$. Thousand grains weight was recorded by weighing thousand grains taken randomly from the grain lot of each sub plot. Data concerning biological yield was taken by reaping four central rows of every sub plot, dried in sun, weighed and then changed to $\mathrm{kg} \mathrm{ha}^{-1}$. The harvested four central rows in each sub plot were threshed, cleaned, weighed and converted to grain yield $\mathrm{kg} \mathrm{ha}{ }^{-1}$. Harvest index was calculated by the following formula.

Harvest index $(\%)=\frac{\text { Grain yield }}{\text { Biological yield }} \times 100$

Method applicable to the randomized complete block design (split-plot arrangement) was used for statistical analysis of the recorded data. For mean comparison in case of significant difference least significant difference (LSD) test at 5\% level of significance was used [26].

\section{Results}

Total tillers $\mathbf{m}^{-2}$

Table 1 showed significant $(\mathrm{P} \leq 0.05)$ effect of nitrogen, phosphorus and varieties $(V)$ on number of total tillers $\mathrm{m}^{-2}$. In interactions only $\mathrm{N} \times \mathrm{P}$ showed a considerable impact on number of total tillers $\mathrm{m}^{-2}$. All interactions except $\mathrm{N} \times \mathrm{P}$ were non-significant. Siran-2010 exhibited greater number of tillers $\mathrm{m}^{-2}$ (377) than Atta-Habib (370). Plots that received 62.5 $\mathrm{kg} \mathrm{N}$ ha $^{-1}$ produced greater number of tillers $\mathrm{m}^{-2}$ (383) than control plots (279). Different phosphorus levels also showed a significant effect on number of tillers $\mathrm{m}^{-2}$. 
Phosphorus level of $90 \mathrm{~kg} \mathrm{ha}^{-1}$ resulted in maximum number of tillers $\mathrm{m}^{-2}$ (379) and less number of tillers $\mathrm{m}^{-2}$ (279) were counted in control plots. In case of interactions between nitrogen and phosphorus, tillers $\mathrm{m}^{-2}$ significantly increased with increasing $\mathrm{P}$ rates up to 90 $\mathrm{kg} \mathrm{ha}^{-1}$ at all $\mathrm{N}$ levels. Varieties, nitrogen, phosphorus and NP interaction considerably $(\mathrm{P} \leq 0.05)$ influenced number of tillers $\mathrm{m}^{-2}$. Highest number of tillers $\mathrm{m}^{-2}$ was maintained by Siran-2010 while lowest by Atta-Habib. The variation in tillers $\mathrm{m}^{-2}$ may be due to genetic variations of these two cultivars. These results are similar with that of [27]. Highest number of tillers $\mathrm{m}^{-2}$ was maintained by $\mathrm{N}$ level of $62.5 \mathrm{~kg} \mathrm{ha}^{-1}$ and minimum was recorded in control plots. This is supported by [28]. Similarly [29] stated that tillering capacity enhanced with increasing $\mathrm{N}$ application. Highest number of tillers $\mathrm{m}^{-2}$ was produced at $\mathrm{P}$ level of $90 \mathrm{~kg} \mathrm{ha}^{-1}$ while lowest was found in control plots. Higher $P$ rates enhanced tillers survival, emergence and yield, especially for secondary tillers [30].

Table 1. Number of total tillers $\mathrm{m}^{-2}$ of wheat varieties as affected by nitrogen and phosphorus fertilization

\begin{tabular}{|ccccc|}
\hline Nitrogen $\left(\mathbf{k g ~ h a} \mathbf{~}^{-1}\right)$ & Phosphorus $\left(\mathbf{k g ~ h a}^{-1}\right)$ & Siran-2010 & Atta-Habib & N x P \\
\hline 50 & 60 & 363 & 358 & 361 \\
50 & 90 & 366 & 357 & 362 \\
50 & 120 & 366 & 357 & 361 \\
62.5 & 60 & 368 & 360 & 364 \\
62.5 & 90 & 402 & 398 & 400 \\
62.5 & 120 & 390 & 379 & 385 \\
75 & 60 & 380 & 374 & 377 \\
75 & 90 & 380 & 372 & 376 \\
75 & 120 & 381 & 375 & 378 \\
\hline 50 & & 365 & 357 & $361 \mathrm{c}$ \\
62.5 & & 387 & 379 & $383 \mathrm{a}$ \\
75 & 60 & 380 & 374 & $377 \mathrm{~b}$ \\
\hline & 90 & 370 & 364 & $367 \mathrm{c}$ \\
& 120 & 383 & 376 & $379 \mathrm{a}$ \\
\hline Mean & & 379 & 370 & $375 \mathrm{~b}$ \\
\hline Control & & $377 \mathrm{a}$ & $370 \mathrm{~b}$ & 374 \\
\hline Rest & & 280 & 278 & 279 \\
\hline
\end{tabular}

LSD value at $\mathrm{P} \leq 0.05$ for varieties $=2.367$

LSD value at $\mathrm{P} \leq 0.05$ for nitrogen $=1.800$

LSD value at $\mathrm{P} \leq 0.05$ for phosphorus $=1.800$

LSD value at $\mathrm{P} \leq 0.05$ for nitrogen $\mathrm{x}$ phosphorus $=5.020$

Mean values of each category followed by different letter (s) are statistically different at P $\leq 0.05$ using LSD test.

\section{Spike $\mathbf{m}^{-2}$}

Data recorded on spikes $\mathrm{m}^{-2}$ is shown in table 2. Mean data revealed that nitrogen, phosphorus, varieties and NP interaction significantly $(\mathrm{P} \leq 0.05)$ affected spikes $\mathrm{m}^{-}$ 2. While the interactions between control vs. rest $\mathrm{x}$ varieties, $\mathrm{N} \times \mathrm{V}, \mathrm{P} \times \mathrm{V}$ and $\mathrm{N} \times \mathrm{P}$ $\mathrm{x} V$ showed a non-significant response.
More spikes $\mathrm{m}^{-2}$ (362) was produced by variety Siran-2010 while lowest spikes $\mathrm{m}^{-2}$ (352) was produced by Atta-Habib. Nitrogen level of $125 \mathrm{~kg} \mathrm{ha}^{-1}$ resulted in highest number of spikes $\mathrm{m}^{-2}$ (368). Less number of spikes $\mathrm{m}^{-2}$ (261) was reported in control plots. In case of phosphorus application maximum spikes $\mathrm{m}^{-2}$ (364) 
were produced by $90 \mathrm{~kg} \mathrm{P} \mathrm{ha}^{-1}$ while minimum spikes $\mathrm{m}^{-2}$ (261) were counted in control plots. In case of $\mathrm{N}$ and $\mathrm{P}$ interactions increased in number of spikes $\mathrm{m}^{-2}$ occurred with increasing $\mathrm{P}$ levels upto $90 \mathrm{~kg} \mathrm{P} \mathrm{ha}^{-1}$ at all levels of $\mathrm{N}$ and then decreased at $120 \mathrm{~kg} \mathrm{P} \mathrm{ha}{ }^{-1}$. The result showed that $\mathrm{N}, \mathrm{P}$ and the interaction of $\mathrm{N}$ and $\mathrm{P}$ significantly $(\mathrm{P} \leq 0.05)$ affected spikes $\mathrm{m}^{-2}$ of wheat varieties. Maximum spikes $\mathrm{m}^{-2}$ was produced by Siran-2010 while minimum was produced by AttaHabib. The probable reason for this might be the variation in genetic makeup of these varieties. Greater number of spikes $\mathrm{m}^{-2}$ was counted at nitrogen application rate of $125 \mathrm{~kg} \mathrm{ha}^{-1}$ lowest was counted in control plots. These results are in line with [31] who reported maximum spikes $\mathrm{m}^{-2}$ at $\mathrm{N}$ rate of $120 \mathrm{~kg} \mathrm{ha}^{-1}$. Highest number of spikes $\mathrm{m}^{-2}$ was counted at $90 \mathrm{~kg} \mathrm{P} \mathrm{ha}^{-1}$ and minimum were counted in control plots. Fertilizer application provides essential plant nutrients well in time and thus might have enhanced the crop efficiency to produce more spikes $\mathrm{m}^{-2}$. [32] stated that NPK application had significant impacts on spikes $\mathrm{m}^{-2}$. These result are supported by [33] who stated that phosphorus application positively influenced productive tillers.

\section{Grains spike ${ }^{-1}$}

Table 2 shows the data with concerning the effects of different levels of nitrogen and phosphorus on number grains spike ${ }^{-1}$ of wheat varieties. From mean data it was concluded that various rates of $\mathrm{P}$ and $\mathrm{N}$ considerably $(\mathrm{P} \leq 0.05)$ influenced number of grains spike $^{-1}$. Among the entire interactions i.e. $\mathrm{N} x \mathrm{P}, \mathrm{N} \times \mathrm{V}, \mathrm{P} \times \mathrm{V}, \mathrm{N} \times \mathrm{P}$ $\mathrm{x} V$ and control vs. rest $\mathrm{x} V$ only the interaction between $\mathrm{N}$ and $\mathrm{P}$ showed significant result on number of grains spike $^{-1}$. Varieties (V) also significantly affected number of grains spike ${ }^{-1}$. Nitrogen rate of $125 \mathrm{~kg} \mathrm{ha}^{-1}$ produced highest number of grains spike ${ }^{-1}$ (51.44) and lowest (40) were counted in control plots. Phosphorus application at the rate of $90 \mathrm{~kg}$ $\mathrm{ha}^{-1}$ developed highest number of grain spike $^{-1}$ (52.44) while lowest (40) were developed by control plots. Highest number of grain spike ${ }^{-1}$ (50.67) was developed by Siran-2010 and less number of grain spike ${ }^{-1}$ (48.04) was produced by Atta-Habib. The interactive response of $\mathrm{N}$ and $\mathrm{P}$ showed that enhancement of grains spike $^{-1}$ increased with increasing $\mathrm{P}$ levels upto $90 \mathrm{~kg} \mathrm{ha}^{-1}$ at all levels of $\mathrm{N}$ and then decreased at $120 \mathrm{~kg} \mathrm{P} \mathrm{ha}^{-1}$. The influence of $\mathrm{N}, \mathrm{P}$ and varieties on grain spike ${ }^{-1}$ were found significant. All the interactions except $\mathrm{N}$ x $\mathrm{P}$ were found non-significant. Grains spike $^{-1}$ is a vital factor that adds to the grain yield of any crop. Siran-2010 produce more grains spike $^{-1}$ than AttaHabib. The difference in grains spike ${ }^{-1}$ might be due to the genetic variations of these varieties. Our results are agreed with that of [27] who reported variations among wheat cultivars for number of grains spike ${ }^{-}$ 1. Nitrogen application positively influenced number of grains spike $^{-1}$. Highest number of grains spike $^{-1}$ was counted in plots treated with of $125 \mathrm{~kg} \mathrm{~N}$ $\mathrm{ha}^{-1}$ and lowest numbers of grains spike ${ }^{-1}$ were counted in control plots. Our results are in line with that of [31] who recorded maximum grains spike ${ }^{-1}$ at $120 \mathrm{~kg} \mathrm{~N} \mathrm{ha}^{-1}$. Our result also supported by [34] who found more grains spike at $120 \mathrm{~kg} \mathrm{~N} \mathrm{ha}^{-1}$. $\mathrm{P}$ application considerably influenced number of grain spike ${ }^{-1}$. More grains spike ${ }^{1}$ was counted at $\mathrm{P}$ rate of $90 \mathrm{~kg} \mathrm{P} \mathrm{ha}^{-1}$ and less number of grains spike ${ }^{-1}$ was recorded in control plots. Our results are at par with that of [34] who also found maximum grains spike ${ }^{-1}$ at $90 \mathrm{~kg} \mathrm{P} \mathrm{ha}^{-1}$.

\section{Thousand grains weight $(\mathrm{g})$}

Statistical analysis of the data showed that $\mathrm{N}, \mathrm{P}$ and $\mathrm{V}$ had significant $(\mathrm{P} \leq 0.05)$ impact on the weight of thousand grains. Interactive response of $\mathrm{N}$ and $\mathrm{P}$ on thousand grains weight also showed significant result while $\mathrm{N} \times \mathrm{V}, \mathrm{P} \times \mathrm{V}, \mathrm{N} \times$ $\mathrm{P} \times \mathrm{V}$ and control vs. rest $\mathrm{x} \mathrm{V}$ were found to be non-significant (Table 2). Variety Siran-2010 developed heavier grains $(42.16 \mathrm{~g})$ as compared to Atta-Habib $(38.73 \mathrm{~g})$. Heavier thousand grains (42.16 
g) were found in plots received $125 \mathrm{~kg} \mathrm{~N}$ $\mathrm{ha}^{-1}$ as compared to control which had thousand grains weight of $30.13(\mathrm{~g})$. With respect to $\mathrm{P}$ levels highest thousands grains weight $(41.21 \mathrm{~g})$ were produced by the plots received $\mathrm{P}$ at the level of $90 \mathrm{~kg}$ ha $^{-1}$ while minimum thousand grains weight $(30.13 \mathrm{~g})$ were found in control plots. Regarding interactive response of $\mathrm{N}$ and $\mathrm{P}$ grain weight linearly increased with increasing both $\mathrm{N}$ and $\mathrm{P}$ levels. Varieties, nitrogen, phosphorus and NP interaction significantly affected thousand grains weight. Grain weight is a major contributing factor that adds to the final yield of a crop. Siran-2010 produced maximum thousand grain weight than Atta-Habib. The difference in thousand grains weight of these two varieties may be attributed to the inherent differences and suitability of the variety to ecological condition. Similar results were obtained by [35]. Nitrogen application considerably influenced thousand grains weight. Nitrogen level of $125 \mathrm{~kg} \mathrm{ha}^{-1}$ produced heavier grains while lighter grains were recorded in control plots. Our result are supported by [31] who achieved maximum thousand grains weight at $120 \mathrm{~kg} \mathrm{~N} \mathrm{ha}^{-1}$. [29] also find increase in thousand grain weight up to $75 \mathrm{~kg} \mathrm{~N}$ feddan $^{-1}$. $\mathrm{P}$ application showed a positive response on the weight of thousand grains. $\mathrm{P}$ level of $90 \mathrm{~kg} \mathrm{P} \mathrm{ha}^{-1}$ produced heaviest grains which was statically similar to that produced by $120 \mathrm{~kg} \mathrm{P}^{-1}$ while lowest were recorded in control plots. Our results are at par with that of [36] who stated significant enhancement in all the growth and yield parameters at $\mathrm{P}$ level of $80 \mathrm{~kg} \mathrm{P}$ $\mathrm{ha}^{-1}$. Highest level of $\mathrm{P}$ in combination with a fix $\mathrm{N}$ rate contributed maximum to transfer physiological attributes and assimilates towards the yield attributes. Our results are similar to the finding of [37] who reported heaviest grains at 12090-60 kg NPK ha-1 respectively.

\section{Biological yield ( $\left.\mathrm{kg} \mathrm{ha}^{-1}\right)$}

Biological yield of wheat varieties was significantly affected $(\mathrm{P} \leq 0.05)$ by different levels of $\mathrm{N}$ and $\mathrm{P}$. The interaction between $\mathrm{N}$ and $\mathrm{P}$ was also significantly affected biological yield $\mathrm{kg} \mathrm{ha}^{-1}$ (table 2). Higher biological yield (10386 kg ha-1) was produced when nitrogen was applied at the rate of $150 \mathrm{~kg} \mathrm{ha}^{-1}$. Control plots resulted in lowest biological yield (7738 $\left.\mathrm{kg} \mathrm{ha}^{-1}\right)$. With reference to the $\mathrm{P}$ application highest biological yield (10298 $\mathrm{kg} \mathrm{ha}^{-1}$ ) was produced by $90 \mathrm{~kg} \mathrm{P} \mathrm{ha}^{-1}$ while least biological yield (7738 $\mathrm{kg} \mathrm{ha}^{-1}$ ) was recorded in control plots. Wheat variety Siran-2010 developed highest biological yield $\left(10060 \mathrm{~kg} \mathrm{ha}^{-1}\right)$ than AttaHabib which produced least biological yield $\left(9977 \mathrm{~kg} \mathrm{ha}^{-1}\right)$. In case of $\mathrm{N}$ x P biological yield increased with increasing $\mathrm{P}$ levels upto $90 \mathrm{~kg} \mathrm{ha}^{-1}$ at all levels of $\mathrm{N}$ and then decreased at $120 \mathrm{~kg} \mathrm{P} \quad \mathrm{ha}^{-1}$. Varieties, N, P and interaction between $\mathrm{N}$ and $\mathrm{P}$ considerably influenced biological yield all others interactions showed nonsignificant results. Siran-2010 produced more biological yield than Atta-Habib when treated with $150 \mathrm{~kg} \mathrm{~N}^{-1}$ along with $90 \mathrm{~kg} \mathrm{P} \mathrm{ha}^{-1}$. This might be due to variations in genetic makeup of these varieties and other ecological factors. [35] and [38] also stated significant difference in biological yield of wheat verities. Increased vegetative phase of the crop resulted in increased biological yield. Maximum biological yield was obtained in plots treated with $150 \mathrm{~kg} \mathrm{~N}^{-1}$. [39] reported that $\mathrm{N}$ application increased biological yield. Similar result was also reported by [27] who stated that $\mathrm{N}$ application linearly increased biological yield. $\mathrm{P}$ application greatly increased biological yield. Highest biological yield was recorded at $\mathrm{P}$ rate of $90 \mathrm{~kg} \mathrm{P} \mathrm{ha}^{-1}$. [40] reported highest biological yield at $\mathrm{P}$ application rate of $120 \mathrm{~kg} \mathrm{P} \mathrm{ha-1}$. Our results are also agreed with that of [36] who got highest biological yield at $80 \mathrm{~kg} \mathrm{P}$ $\mathrm{ha}^{-1}$.

Grain yield (kg ha-1).

Statistical analysis of the data indicated that $\mathrm{N}, \mathrm{P}$ and $\mathrm{V}$ had significant $(\mathrm{P} \leq 0.05)$ effect on grain yield $\left(\mathrm{kg} \mathrm{ha}^{-1}\right)$. Interactive 
response of $\mathrm{N}$ and $\mathrm{P}$ on grain yield $\mathrm{kg} \mathrm{ha}^{-1}$ also showed significant result. $\mathrm{N} x \mathrm{~V}, \mathrm{P} \times$ $\mathrm{V}, \mathrm{N}$ x P x V and control vs. rest x V were found non-significant (Table 2). Wheat variety Siran-2010 produced greater grain yield (3855 kg ha $\left.{ }^{-1}\right)$ than Atta-Habib which produced grain yield of $3729 \mathrm{~kg} \mathrm{ha}^{-}$ 1 . Highest grain yield (4061 $\mathrm{kg} \mathrm{ha}^{-1}$ ) was found in plots received $125 \mathrm{~kg} \mathrm{~N} \mathrm{ha}^{-1}$ than control. With respect to $\mathrm{P}$ levels greater grain yield (3944 kg ha-1) was recorded in plots in which $\mathrm{P}$ was applied at the rate of $90 \mathrm{~kg} \mathrm{ha}^{-1}$ while minimum grain yield $\left(1879 \mathrm{~kg} \mathrm{ha}^{-1}\right)$ was found in control plots. The interactive response of $\mathrm{N}$ and $\mathrm{P}$ revealed that grain yield increased by increasing $\mathrm{P}$ levels upto $90 \mathrm{~kg} \mathrm{ha}^{-1}$ at all levels of $\mathrm{N}$ and then decreased at $120 \mathrm{~kg} \mathrm{P}$ $\mathrm{ha}^{-1}$. Grain yield of wheat varieties was significantly affected by $\mathrm{N}, \mathrm{P}$ and $\mathrm{N} \times \mathrm{P}$. Achievement of highest grain yield is the ultimate goal of many research project. The main objective of fertilizer application is to get best yield in terms of quantity as well as quality. Wheat variety Siran-2010 produced highest grain yield when treated with $125 \mathrm{~kg} \mathrm{~N}^{-1}$ along with $90 \mathrm{~kg} \mathrm{P} \mathrm{ha}^{-1}$ than Atta-Habib. This is because of more number of spikes $\mathrm{m}^{-2}$, heaver grains and more number of grains spike ${ }^{-1}$. Lowest grain yield was obtained from control plots. Such a result obtained by [41]. The others probable reason might be the variations in genetic potential of both varieties and environmental factors [42]. Nitrogen application significantly increased grain yield. In term of $\mathrm{N}$ application grain yield was maximum at $125 \mathrm{~kg} \mathrm{~N} \mathrm{ha}{ }^{-1}$ while minimum were produced by control plots. Our results are similar to the finding of [43] who stated considerable increased in grain yield at $120 \mathrm{~kg} \mathrm{~N} \mathrm{ha}^{-1}$. P application also enhanced grain yield. Highest grain yield was recorded at $90 \mathrm{~kg} \mathrm{P} \mathrm{ha}^{-1}$ and minimum was recorded in control plots. Our results are similar to the finding of [36] who reported maximum grain yield at $80 \mathrm{~kg} \mathrm{P} \mathrm{ha}{ }^{-1}$. Similarly [34] reported that $120 \mathrm{~kg} \mathrm{~N} \mathrm{ha}^{-1}$ along with $90 \mathrm{~kg} \mathrm{P} \mathrm{ha}^{-1}$ is a suitable rate for getting maximum wheat production.

\section{Harvest index (\%)}

Statistical analysis of the data showed that $\mathrm{N}, \mathrm{P}$ and $\mathrm{V}$ considerably $(\mathrm{P} \leq 0.05)$ affected harvest index. Among interactions only $\mathrm{N}$ x $\mathrm{P}$ showed significant effect on harvest index (table 2). Wheat variety Siran-2010 maintained greater harvest index $(38.5 \%)$ followed by Atta-Habib $(37.69 \%)$. Greater harvest index (40.9\%) was recorded at $125 \mathrm{~kg} \mathrm{~N}$ ha $^{-1}$ while lowest harvest index $(24.3 \%)$ in control plots. Phosphorus rate of $90 \mathrm{~kg} \mathrm{ha}{ }^{-1}$ produced highest harvest index $(38.8 \%)$ and lowest $(24.3 \%)$ in control plots. $\mathrm{N}$ x P developed highest harvest index (43.4\%) at nitrogen rate of $125 \mathrm{~kg} \mathrm{ha}^{-1}$ and $\mathrm{P}$ rate of $90 \mathrm{~kg} \mathrm{ha}^{-1}$. Regarding the interactive effect of nitrogen and $\mathrm{P}$ the harvest index increased upto $125 \mathrm{~kg} \mathrm{~N}^{-1}$ and $90 \mathrm{~kg} \mathrm{P}$ $\mathrm{ha}^{-1}$ and then tends to decreased at $150 \mathrm{~kg}$ $\mathrm{N} \mathrm{ha}^{-1}$ and $120 \mathrm{~kg} \mathrm{P} \mathrm{ha}^{-1}$. Harvest index was significantly affected by varieties, nitrogen and phosphorus and $\mathrm{N} \times \mathrm{P}$ all others interactions showed non-significant results. Siran-2010 produced maximum harvest index than Atta-Habib when treated with $125 \mathrm{~kg} \mathrm{~N}^{-1}$ along with 90 $\mathrm{kg} \mathrm{P} \mathrm{ha}{ }^{-1}$ and minimum were recorded in control plots. This might be due to variations in genetic makeup of these varieties and other ecological factors. Our results also supported by [38] who stated significant difference in harvest index of wheat varieties. $\mathrm{N}$ application increased vegetative phase of the crop which resulted in increased biological yield as a result harvest index decreased. Maximum harvest index was obtained in plots received $125 \mathrm{~kg} \mathrm{~N}^{-1}$ while lowest were recorded in control plots. Our results are supported by [31] who reported that $\mathrm{N}$ application at the level of $120 \mathrm{~kg} \mathrm{ha}^{-1}$ gave maximum harvest index. $\mathrm{P}$ application greatly increased harvest index. Highest harvest index was recorded in the plots received $90 \mathrm{~kg} \mathrm{P} \mathrm{ha}^{-1}$ that was statistically similar to that produce by $120 \mathrm{~kg} \mathrm{P} \mathrm{ha}^{-1}$ while lower were recorded in control plots. 
[6] reported that $\mathrm{P}$ fertilizer greatly improved harvest index.

Table 2. Number of spikes $\mathrm{m}^{-2}$, grains spike ${ }^{-1}, 1000$ grains weight, biological yield, grain yield and harvest index of wheat varieties as affected by nitrogen and phosphorus fertilization

\begin{tabular}{|c|c|c|c|c|c|c|}
\hline 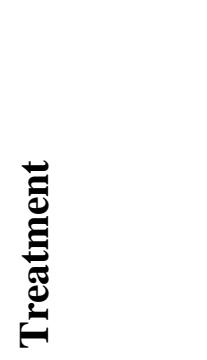 & 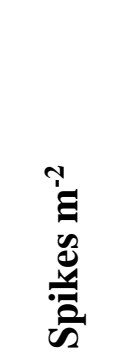 & 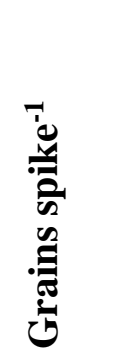 & 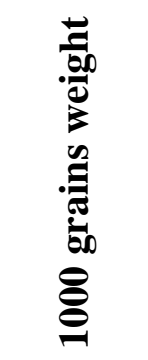 & $\frac{\sigma}{\frac{\sigma}{2}}$ & 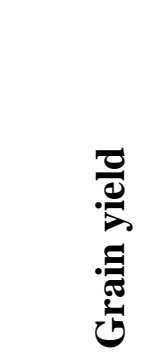 & 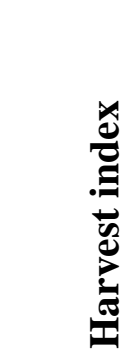 \\
\hline \multicolumn{7}{|l|}{$\mathbf{N}\left(\mathrm{kg} \mathrm{ha}^{-1}\right)$} \\
\hline 100 & $345 c$ & $46.83 c$ & $37.22 \mathrm{c}$ & $9626 c$ & $3423 c$ & $35.6 c$ \\
\hline 125 & $368 \mathrm{a}$ & $51.44 \mathrm{a}$ & $42.16 \mathrm{a}$ & $10044 b$ & $4061 \mathrm{a}$ & $40.9 \mathrm{a}$ \\
\hline 150 & $358 b$ & $49.78 b$ & $40.46 b$ & 10386a & $3892 b$ & $37.5 b$ \\
\hline LSD (0.05) & 2.286 & 0.965 & 1.308 & 34.910 & 63.969 & 0.623 \\
\hline \multicolumn{7}{|l|}{$\mathbf{P}\left(\mathrm{kg} \mathrm{ha}^{-1}\right)$} \\
\hline 60 & $351 \mathrm{c}$ & $46.72 \mathrm{c}$ & $38.33 b$ & $9751 \mathrm{c}$ & $3676 c$ & $37.7 b$ \\
\hline 90 & $364 a$ & $52.44 \mathrm{a}$ & $41.21 \mathrm{a}$ & $10298 \mathrm{a}$ & $3944 a$ & $38.8 \mathrm{a}$ \\
\hline 120 & $356 b$ & $48.89 \mathrm{~b}$ & $40.31 \mathrm{a}$ & $10007 b$ & $3756 \mathrm{~b}$ & $38.4 \mathrm{a}$ \\
\hline LSD (0.05) & 2.286 & 0.965 & 1.308 & 34.910 & 63.969 & 0.623 \\
\hline \multicolumn{7}{|l|}{ Varieties } \\
\hline Siran-2010 & $362 a$ & $50.67 \mathrm{a}$ & $41.16 \mathrm{a}$ & 10060a & $3855 \mathrm{a}$ & $38.7 \mathrm{a}$ \\
\hline Atta-Habib & $352 b$ & $48.04 \mathrm{~b}$ & $38.73 b$ & $9977 b$ & $3729 b$ & $37.8 \mathrm{~b}$ \\
\hline $\operatorname{LSD}(0.05)$ & 2.457 & 0.816 & 0.669 & 29.976 & 29.318 & 0.339 \\
\hline Control & 261 & 40.00 & 30.32 & 7738 & 1879 & 24.3 \\
\hline \multicolumn{7}{|c|}{ Interaction } \\
\hline $\mathrm{N} \times \mathrm{P}$ & $*$ & $*$ & $*$ & $*$ & $*$ & * \\
\hline
\end{tabular}

Mean values of each category followed by different letter (s) are statistically different $\quad$ at $\mathrm{P} \leq 0.05$ using LSD test

\section{Conclusion and recommendation}

It is concluded from the experiment that wheat variety Siran-2010 performed better than Atta-Habib in terms of yield and yield components. Nitrogen application at the rate of $125 \mathrm{~kg} \mathrm{ha}^{-1}$ produced maximum grain yield. Phosphorus application up to $90 \mathrm{~kg} \mathrm{ha}^{-1}$ showed better impact on growth and yield. Wheat variety Siran-2010 is recommended for general cultivation due to its better yield performance. Phosphorus level of $90 \mathrm{~kg} \mathrm{ha}^{-1}$ is recommended on the basis of higher grain yield. Nitrogen level of $125 \mathrm{~kg} \mathrm{ha}^{-1}$ is recommended for higher grain yield.

\section{Authors' contributions}

Conceived and designed the experiments: $S$ Anwar \& Israeel, Performed the experiments: Israeel, B Iqbal \& S Khan, Analyzed the data: S Anwar \& Israeel, Provided reagents: M Faraz, N Ali, S Hussain \& MM Anjum, Wrote the paper: S Anwar \& B Iqbal.

\section{References}

1. Malik MA, Irfan M, Ahmed ZI \& Zahoor F (2006). Residual effect of summer grain legumes on yield and yield components of wheat (Triticum aestivum L.). Pak J Agric Agril Engg Vet Sci 22: 9-11.

2. Tuino SD, Korejo MN, Jarwar AD \& Waggan MR (2006). Studies on 
indigenous and exotic weed competition in wheat. Pak J Agric Engg Sci 22: 1.

3. Heyan EG (1987). Wheat and wheat improvement. $2^{\text {nd }}$ ed. Madison, Wisconsin, USA.

4. MINFA (2011). Agricultural statistics of Pakistan. Govt. of Pakistan, Islamabad.

5. Ahmed N \& Rashid M (2004). Fertilizer and their use in Pakistan. Govt of Pak Plan and Dev Div NFDC, Islamabad.

6. Alam SM, Shah SA, Latif A \& Iqbal Z (2002). Performance of some wheat varieties to fertigation applied phosphorus sources. Pak J Soil Sci 11(2): 123-125.

7. FAO (1990). Fertilizer yearbook 1990. Rome.

8. Sadik N (1992). The state of world population. New York, NY, USA. United Nations Population Fund. P. 38-45.

9. Byerlee D \& Siddiq AA (1994). Has the green revolution been maintained? The quantitative impact of the seedfertilizer revolution in Pak. Revisited. World Devel. 22: 1345-1361.

10. Ahmad N, Rashid M \& Vaes AG (1996). Fertilizer efficiency. Int: (Eds):N. Fertilizers and their use in Pakistan. NFDC Pub Islamabad. P.166.

11. Geleto T, Tanner DG, Mamo $\mathrm{T} \&$ Gebeyenu G (1995). Response of rainfed bread and Durum wheat to source, level and timing of nitrogen fertilizer on yield and yield components of two Ethiopian varieties. Common Soil Sci and Pl Anal 26(12): 1773-1794.

12. Heichel GH \& Barnes DK (1984). Opportunities for meeting crop nitrogen needs from symbiotic nitrogen fixation. 49-59. In :( Ed.): D.F. Bezdicek et al., Organic farming Current technology and its role in sustainable agriculture. Special publication. No. 46. ASA, Madison, WI.
13. Olson RV \& Kurtz LT (1982). Crop nitrogen requirement, utilization and fertilization. p. 567-604. Int: (Ed.): F. J. Stevenson. Nitrogen in agricultural soils. ASA, Madison, WI.

14. Behera UK \& Sharm KC (1991). Effect of irrigation in fertility levels on the yield of wheat in Tarai. Orissa $J$ Agric Res (1- 2): 130-2.

15. Singh VP \& Uttam SK (1992). Response of wheat cultivars to different nitrogen levels under sown conditions. Crop Res. 5: 82-6.

16. Warraich EA, Ahmad N, Basra SMA \& Afzal I (2002). Effect of nitrogen on source-sink relationship in wheat. Int $J$ Agric Bio. 4: 300-02.

17. Wilhelm WW (1998). Dry matter partitioning and leaf area of winter wheat grown in a long term fallow tillage comparisons in U.S. Central Great Plans. Soil and Tillage Res. 49: 49-56.

18. Ahmed S, Jan NE, Khan R, Faridullah \& Din N (2010). Wheat response to Phosphorous under climatic conditions of Juglote Pakistan. Sarhad J Agric. 26(2): 229-233.

19. Camargo C, Felicio JC, Freitas JG \& Paulo S (2000). Evaluation of wheat cultivars for phosphorus efficiency on acid soils and in nutrient solution. Ecol Agric and Sus Dev. 2: 289-29.

20. Cisse L \& Amar B (2000). The importance of phosphatic fertilizer for increased crop production in developing countries. In: Proceedings of the AFA $6^{\text {th }}$ International Annual conference held on $31^{\text {st }}$ Jan and 2nd Feb. 2000. Cairo, Egypt.

21. Senigagliesi CA, Garcia R, Meria S, Galetto MLR, Defrusos E \& Teves R (1983). Fertilizer application to wheat in the north of province of Buyenos Aires and south of Santafe. Agropecuaria Pergamino. Argentiana. J Field Crop. 37(7): 5117-1984.

22. Richards JF, Graham PH \& Eichorn BM (1985). Effect of super phosphate 
and nitrogen on yield of wheat. New Zealand J Crop Hort. 11: 103-8.

23. Imtiaz M, Shah KH, Khan P, Siddiqui SH, Memon MY \& Aslam M (2003). Response of wheat genotype S1-91195 to increasing $\mathrm{N}$ and $\mathrm{P}$ levels and their ratios under agro-climatic conditions of Sindh. Pak J soil Sci. 22: 58-63.

24. Salimpour S, Khavazi K, Nadian H, Besharati H \& Miransari M (2010). Enhancing phosphorous availability to canola (Brassica napus L.) using $\mathrm{P}$ solubilizing and sulfur oxidizing bacteria. Aust J Crop Sci. 4(5): 330334.

25. Jiang ZQ, Feng CN, Huang LL, Guo WS, Zhu XK \& Peng YX (2006). Effect of phosphorus application on dry matter production and phosphorus uptake in wheat. Plant Nut and Fert Sci. 12(5): 628-634.

26. Steel RGD \& Torrie JH (1980). Principles and procedure of statistics. A biological approach $2^{\text {nd }}$ ed. McGraw Hill Inc. New York.

27. Ahmad A, Mahmood N \& Akhtar B (1997). Effect of different depths of irrigation on the grain yield of promising late sown wheat cultivars. Rachis. 16(1-2): 77-80.

28. Yasmeen A \& Shah SH (2000). Quantitaive and qualitative response of three wheat varities to nitrogen application. Pak J Bio Sci 3(10): 5541546.

29. Salwau MJM (1994). Effect of soil and foliar application of nitrogen levels on yield and yield components of wheat (Titicum aestivum L.). Ann Agric Sci Moshtohor. 32(2): 705-715.

30. Fioreze SL, Castoldi G, Pivetta LA, Pivetta LG, Fernandes DM \& Büll LT (2012). Tillering of two wheat genotypes as affected by phosphorus levels. Acta Scientiarum Agric 34(3): 331-338.

31. Khalil SK, Khan F, Rehman A, Muhammad F, Amanullah, Khan AZ, Shah MK \& Khan H (2011). Dual Purpose wheat for forage and grain yield in response to cutting, seed rate and nitrogen. Pak J Bot. 43(2): 937947.

32. Rehman S, Khalil SK, Rehman A \& Saljoqi AUR (2008). Organic and inorganic fertilizer increase wheat yield components and biomass under rainfed condition. 2008. Sarhad J Agric 24(1):11-20.

33. Mattas KK, Upal RS \& Singh RP (2011). Effect of varieties and nitrogen management on the growth, yield and nitrogen uptake of durum wheat. Research J agric Sci. 2(2): 376-380.

34. Parvez K, Imiaz M, Aslam M \& Shah SKH (2008). Effect of different nitrogen and phosphorus ratios on the performance of wheat cultivar khirman. Sarhad J Agric. 24(2): 233240.

35. Al-doss AA, Al-Hazmi AS, Dawabh AM, Abdel-Mawgood AA, AlRehiayani SM, Al-Otayk S, Mousatafa KA \& Motawei MI (2010). Impact of Cre and peroxide genes of selected new wheat lines on cereal cyst nematode (Heterrodera avenae woll) resistance Aust J crop Sci. 4(9): 737743.

36. Khan MB, Lone MI, Ullah R, Kaleem S \& Ahmed M (2010). Effect of different phosphatic fertilizers on growth attributes of wheat (Triticum aestivum L.). J Am Sci. 6(12): 12561262.

37. Khan MA, Jan N, Sultana Q, Ahmad SR \& Rahman A (2006). Effect of different organic materials and chemical fertilizer on the yield of wheat and physical properties of soil. Sarhad. J. Agric. 22(3): 38-44.

38. Bisht JK, Kant L \& Srivasta AK (2008). Cutting management of dual purpose wheat cultivars; a new approach for increasing fodder availability. Cereal Research Communications. 36(1): 177-187.

39. Noy-Meri I \& Brisk DD (1996). Fitness components of grazing-induced population reduction in dominant 
annual wild wheat. $J$ Appl Ecol 84 (3): 438-448.

40. Nazim H, Khan MB \& Ahmad R (2008). Influence of phosphorus application and sowing time on performance of wheat in calcareous soils. Int J Agric Bio 10(4): 399-404.

41. Tahir M, Tanveer A, Ali A, Ashraf M \& Wasaya A (2008). Growth and yield response of two wheat (triticum aestivum L.) varieties to different potassium levels. Pak J Life Soc Sci 6(2): 92-95.

42. Munsif F \& Arif M (2011). Effect of planting dates on the potential use of dual purpose wheat cultivars. Ph.D. Thesis. KPK Agric Univ Peshawar.

43. Ram T, Yadav SK \& Sheoran RSS (2002). Nutrient uptake pattern of wheat (Triticum aestivum L.) as influenced by azotobacter and nitrogen fertilization environment and ecology. Envi Ecol 20(3): 661-665. 